PAEDAGOGIA CHRISTIANA

2/26(2010) - ISSN 1505-6872

Katarzyna Wrońska*

Kraków

\title{
Rodzina chrześcijańska jako środowisko budowania społeczeństwa obywatelskiego
}

Stawianie naprzeciw siebie z jednej strony polskiej rodziny, z drugiej społeczeństwa obywatelskiego to problem dla badacza bardzo interesujący, bo mało spenetrowany, ale niełatwy. Więcej w nim pytań niż odpowiedzi. Poniższa analiza jest próbą zbliżenia obu rzeczywistości, przyjrzenia się im pod kątem ich wzajemnej przystawalności, bycia w relacji, wpływania na siebie, wspierania się bądź hamowania w swych formach przejawu. Na pierwszy rzut oka obie rzeczywistości jawią się jako odrębne, pochodzące niejako z dwóch różnych wymiarów.

Po pierwsze, rodzinę postrzegamy przede wszystkim przez pryzmat jej realnych kształtów, jako rzeczywistość konkretna, namacalną, dostępną dla empirycznego badania i wglądu, natomiast społeczeństwo obywatelskie to bardziej projekt, idea niż realność dostępna dla postronnego obserwatora. Badanie wzajemnych między nimi relacji to więc w głównej mierze pytanie o wpływ idei na rzeczywistość, i na odwrót, o wpływ rzeczywistości na ideę. W naszym przypadku chodzić będzie o zbadanie rozumienia i recepcji idei społeczeństwa obywatelskiego w polskich rodzinach oraz o zbadanie szans i zagrożeń, mocnych i słabych stron realizacji tej idei, mając za punkt wyjścia zestaw norm, tradycji i cnót pielęgnowanych i przekazywanych z pokolenia na pokolenie w rodzinnych wspólnotach, wywierających wpływ na kształt kultury naszego społeczeństwa. Interesujące jest w tym kontekście także przyjrzenie się samej idei obywatelskości pod kątem jej obecności w polskiej tradycji, na ile jest ona, podobnie jak rodzina, polską realnością,

* Dr Katarzyna Wrońska, adiunkt w Instytucie Pedagogiki Uniwersytetu Jagiellońskiego. 
wypracowanym doświadczeniem, do którego można się odwoływać i nawiązywać, a na ile ideą zaczerpniętą z zewnątrz, spoza rodzimej myśli i tradycji; stąd pytania wielu uczonych, czy tę ideę w Polsce trzeba „sadzić”, „budować” czy „pielęgnować”, „chronić”.

Po drugie, odrębność obu przedmiotów badań wynika z faktu, że rodzina od czasów starożytnych była, i jest do dziś, postrzegana w kategoriach domostwa i wspólnoty gospodarowania, siedliska życia i rozwoju człowie$\mathrm{ka}$, „miniatury systemu społecznego”, ale uprzedniej wobec państwa (wypełniającej sferę przedpolityczna), mającej prawo chronić obszar własnej prywatności (całości pożycia kobiety, mężczyzny i ich potomstwa) przed oczami innych i ingerencją władzy, natomiast społeczeństwo obywatelskie to przestrzeń postaw i działań osób-obywateli, wykraczających tak pod względem celów, jak i zasięgu poza obszar czterech ścian domu, a więc poza sferę prywatna, budujących przestrzeń publiczną w sieci zrzeszeń, ruchów, grup, stowarzyszeń, otwartą na wzrok i ocenę innych jej uczestników, obserwatorów czy krytyków, a także polityki i władzy, choć autonomiczną i niezależną wobec państwa. Stawianie naprzeciw siebie rodziny i społeczeństwa obywatelskiego umożliwia więc badanie poziomu zdolności i gotowości przekraczania przez osoby prywatne sfery zakreślonej przez interesy i potrzeby wspólnoty rodzinnej i wchodzenia, na zasadzie dobrowolności, w relacje społeczne szersze niż te oparte na pokrewieństwie.

W polskiej rzeczywistości interesujące jest poznawanie postaw obywatelskich naszych rodaków, poczynając od badania stopnia znajomości przez nich ich własnych praw jako obywateli oraz ich obowiązków wobec wspólnoty tak lokalnej, jak i szerszej ${ }^{3}$ (czyli świadomości bycia obywatelem), czego świadectwem jest otwarcie na problemy lokalnej wspólnoty, a także na sprawy publiczne dotyczące całego społeczeństwa, narodu, państwa, kończąc na badaniu ich umiejętności i gotowości do społecznej samoorganizacji, podejmowania spontanicznych zachowań społecznych, angażowania się w działalność różnego rodzaju kół, klubów, towarzystw (hobbystycznych, sportowych, wyznaniowych itp.), rozwiązywania różnych problemów lokalnych/grupowych oddolnie bez czekania na działania odgórne, zdolności do podejmowania dobrowolnych działań wspólnie z innymi w sprawach o różnym zasięgu (od sąsiedzkiej samopomocy, przez zaangażowanie w życie parafialne, w prace samorządu terytorialnego, po działanie w ogólnopolskich czy międzynarodowych organizacjach i gremiach).

1 Zob. J. Szacki, Liberalizm po komunizmie, Kraków 1994, s. 74.

${ }^{2}$ G. Himmelfarb, Jeden naród dwie kultury, Warszawa 2007.

3 Zob. postulowana przez Jana Pawła II w ostatnim Orędziu na Światowy Dzień Pokoju 1.01.2005 roku zasada światowego obywatelstwa. 
Jeśli zakłada się, że bycia obywatelem trzeba się uczyć, niejako wprawiać się do tej roli, co jest procesem rozłożonym na lata, to stajemy przed pytaniem, jak z tym zadaniem radzi sobie polska rodzina? Czy nasza rodzinna kultura, wzory zachowań, postawy, przekonania, wpajane wartości, charakteryzujące polskie społeczeństwo, sprzyjają krzewieniu cnót obywatelskich, i czy są z nimi zbieżne? Są badacze, którzy podkreślają wyraźny wpływ na poziom społecznego zaangażowania obywateli właśnie kultury rodzinnej ${ }^{4}$. Czy wartości moralne i społeczne kultywowane w polskich rodzinach mają szansę wyposażyć nasze dzieci w ten kapitał społeczny, który uzdolni je do bycia aktywnymi i odpowiedzialnymi obywatelami? Czy kultura wychowawcza w polskich rodzinach sprzyja rozwojowi postaw obywatelskich, czy je hamuje? Jaką wage przywiązują one do spraw publicznych? Wydaje się, że trzeba tu dodatkowo uwzględnić jakiś pozarodzinny kompleks mocniejszych czynników społeczno-kulturowo-politycznych a także historycznych, wpływających na taką a nie inną dostępność, popularność i rozpowszechnienie samej idei społeczeństwa obywatelskiego w Polsce, czego konsekwencją jest takie a nie inne przejawianie się tej idei w praktyce. Wiemy, że na obu poziomach wypadamy raczej słabo. Mogłoby to stawiać rodzinę w pozycji czynnika potencjalnie pozytywnego (zważywszy na rolę, jaką spełnia w procesie moralnego i religijnego wychowania młodego pokolenia), jednak praktycznie wycofanej co najmniej do pozycji faktora neutralnego, jeśli już nie mówić o negatywnej roli hamulcowego. Interesujące badawczo jest też pytanie o wpływ składników kultury rodzinnej na poziom społecznego zaufania w naszym społeczeństwie (wiedząc, że jest on, w porównaniu z innymi krajami Europy, niski), a także badanie przyczyn, dla których religijność Polaków daje się łączyć z postawami braku zaufania społecznego oraz słabym zaangażowaniem społecznym i obywatelskim. Pozostaje też na koniec pytanie czysto pedagogiczne, jak radzić sobie z przywołanymi wyżej trudnościami i barierami oraz w jaki sposób i jakie podmioty mogą i powinny wspierać rodziny, uwzględniając ich duże zróżnicowanie środowiskowe i odmienność kultywowanej tradycji, do zaangażowania społecznego/obywatelskiego jej członków, głównie młodego pokolenia? Jak pomóc ożywić pozytywny potencjał tkwiący w polskich rodzinach, a jak uzupełnić jego brak?

Niniejszy tekst jest próbą odpowiedzi, choć w części, na wywołane problemy i pytania. Przyznaję, że sformułowałam je jakiś czas temu i teraz, gdy podejmuję je na nowo, wracając do nich po przerwie, wydają mi się jeszcze bardziej złożone i równie trudne do rozwiązania. Wiążę tę trudność z rozbiciem ideowo-politycznym z ostatnich lat, bezpardonową walką o miejsce na

${ }^{4}$ Takie korelacje dostrzegał w XIX wieku A. de Tocqueville, dziś pisze o nich np. F. Fukuyama. 
szczytach władzy i rząd dusz, która nie pozostawiła pojęcia obywatelstwa poza nią, ale właśnie włączyła je w sam środek sporu. Tak więc dziś mówienie - w Polsce - o społeczeństwie obywatelskim bywa równoznaczne $\mathrm{z}$ opowiedzeniem się po jednej ze stron politycznego spektrum. Gdy pierwszy raz podejmowałam ów temat, teoretycznie a także z pomocą badań empirycznych, miałam przekonanie, że samą ideę społeczeństwa obywatelskiego da się traktować ponad podziałami jako ideę symbolizującą jednostkową i społeczną podmiotowość $\mathrm{w}$ demokratycznym społeczeństwie, w państwie wolnym od totalitarnych rządów, a nawet jako pojęcie socjologiczne w miarę neutralne światopoglądowo, nadające się do opisu poziomu społecznej aktywności ${ }^{5}$ danej populacji; dziś sytuacja kształtuje się inaczej. Część społeczeństwa dała się przekonać liderom politycznym, że Polska liberalna i obywatelska to antyteza Polski solidarnej. Idea, która w latach 90. XX wieku była jeszcze, jak się wydaje, ideą ożywiającą i jednoczącą społeczeństwo, a nawet krzepiąca umysły intelektualistów zachodnich śledzących ruch odradzania się sił społecznych obozu postkomunistycznego, dziś anektowana jest do walki politycznej, jako oręż w walce o Polskę różnych partyjnych barw. Nakłada się na to postawa dystansu a nawet nieufności wobec obywatelskich ruchów wypowiadana ze strony niektórych hierarchów Kościoła czy jeszcze częściej z ambon kościołów parafialnych, podgrzewana antyklerykalnymi głosami niektórych lewicowych organizacji, przywołując stary konflikt doktrynalny toczony między Kościołem i jego myślą społeczną a liberalizmem (wydawało się, że już mocno złagodzony dzięki dokonaniom Soboru Watykańskiego II i encyklikom społecznym Jana Pawła II). To zjawisko, czyli upolitycznienie idei społeczeństwa obywatelskiego, może się okazać jedną z przyczyn hamujących społeczne zaangażowanie w Polsce. Poniższy tekst jest próbą wyjścia poza tę dychotomię; stawia sobie za zadanie opisanie kondycji polskiej rodziny w aspekcie rozwoju solidarności obywatelskiej, traktując obywatelskość (postawę obywatelską) jako pozytywny wyróżnik tak jednostek, jak i społeczeństwa, pamiętając o podwójnym ideowym rodowodzie obywatelstwa (republikańskim, liberalnym) ${ }^{6}$ oraz w nawiązaniu do przywołanych wyżej przykładów akademickiego dyskursu (wolnych od politycznych/partyjnych uwikłań), które traktuję jako szkoły budowania rzetelnego warsztatu, prowadzenia pogłębionych analiz oraz inspirowania do podejmowania pozytywnych działań więziotwórczych i integrujących społecznie.

${ }^{5}$ W takich ujęciach spotykamy ją np. w tekstach E. Shilsa, D. Bella, F. Fukuyamy, R. Bellaha czy R. Putnama, którego najnowszą pracę Samotna gra w kręgle. Upadek i odrodzenie wspólnot lokalnych $w$ Stanach Zjednoczonych można uznać na tym polu za modelową.

${ }^{6}$ Czy nawet potrójnym, jeśli nie zapomnimy o wpływie tradycji ruchów socjalistycznych (byleby nie mylić tej tradycji z realnym socjalizmem, grabarzem społeczeństwa obywatelskiego). 


\section{Idea społeczeństwa obywatelskiego w polskiej rzeczywistości}

Większość badaczy społeczeństwa obywatelskiego przyjmuje zgodnie, że sama idea, której początków można doszukiwać się już w starożytnych koncepcjach politycznych Arystotelesa i Cycerona, najintensywniej rozwinęła się w czasach nowożytnych, czerpiąc $\mathrm{z}$ dwóch tradycji myśli politycznej: republikańskiej (Machiavelli, J. Bodin, J. J. Rousseau) i liberalnej (J. Locke, T. Hobbes, A. Ferguson, I. Kant, A. de Tocqueville, J. Stuart Mill), by po Heglu i Marksie od połowy XIX wieku nieco w Europie przygasnąć (w Stanach Zjednoczonych zaangażowanie obywatelskie w tym czasie nie odniosło porównywalnych strat) i na powrót odrodzić się tu w XX wieku. W Polsce i w pozostałych krajach Europy Środkowo-Wschodniej obecność tej idei zaznaczyła się dość wyraźnie najpierw w 1980 roku, potem na przełomie lat 80. i 90., a to za sprawą wyzwalania się społeczeństw bloku sowieckiego spod dominacji systemu komunistycznego, środkami samoorganizacji i społecznych masowych inicjatyw, które skupiły uwagę obserwatorów i badaczy społecznych wieszczących odrodzenie na nowo, więdnących w Europie i Ameryce, postaw obywatelskich. Zryw wielomilionowego ruchu „Solidarności” opisywany był w kategoriach ruchu obywatelskiego o mocnym kapitale społecznego zaufania, łączącym różne grupy i warstwy społeczne. Czy poza tym „solidarnościowym” ruchem w Polsce możemy odnaleźć i odwołać się do innych historycznych śladów obecności tradycji obywatelskiej?

W moim przekonaniu czas międzywojnia w Polsce to przykład rozwoju postaw zaangażowania społecznego i samorządności, pobudzonych zrywem patriotycznym po odzyskaniu niepodległości i powrocie na mapy polityczne Europy jako niezawisłej i suwerennej Rzeczypospolitej, poprzedzony długim, półtorawiekowym okresem podległości i wynaradawiania. Ten krótki czas jednego 20-lecia we wspomnieniach Polaków z tamtego okresu pozostaje pomimo burzliwych politycznych momentów czasem ożywienia społecznego, odradzania się różnych tradycji współdziałania, zrzeszania się, sąsiedzkiej samopomocy, lokalnej samorządności'; zarazem jest to czas rozkwitu myśli społecznej różnej orientacji, z wyróżniającym się na gruncie pedagogiki społecznej wkładem H. Radlińskiej czy St. Karpowicza, następnie takich postępowych pisarzy, uczonych i działaczy, jak m.in. E. Abramowski,

7 Taki obraz Polski kresów wschodnich czasów międzywojnia o wyraźnym wielokulturowym wymiarze etnicznym, $\mathrm{z}$ dobrosąsiedzkimi relacjami, zaradnością i społecznikowskim zaangażowaniem a zarazem z silnym patriotyzmem i szacunkiem dla władz lokalnych i zwierzchnich wyłania się np. z opowieści mojego ojca. 
St. Brzozowski, J. Korczak, S. Sempołowska, J. W. Dawid, I. Moszczeńska czy tworzących nurt obywatelsko-propaństwowy, jak: S. Czerwiński, K. Sośnicki czy Z. Mysłakowski ${ }^{8}$. Jako manifest myśli i postawy obywatelskodemokratycznej można bez wątpienia wskazać pracę M. Ossowskiej z 1946 pt. Wzór obywatela w ustroju demokratycznym.

Wcześniejsze trwanie pod zaborami trudno byłoby nazwać czasem sprzyjającym krzewieniu obywatelskich cnót, bardziej nadawał się on na ćwiczenie strategii przystosowawczych (podobnie jak w okresie władzy ludowej), z drugiej strony opór wobec obcego władztwa dawał aktywnym społecznie Polakom, patriotom asumpt do łączenia wysiłków na rzecz uwalniania się spod autorytarnej obcej władzy i znajdowania (częściej wywalczania) obszarów swobodnej działalności. Najbardziej spektakularnymi przykładami takich działań były zrywy powstańcze, walka narodowowyzwoleńcza, jednocząca ludzi we wspólnym działaniu przeciw zaborcy/okupantowi. Każdy z zaborów był też areną tworzenia się opozycyjnych grup działaczy, organizujących się w imię postępu, szerzenia oświaty, ograniczania nierówności wynikających z trwania wciąż pozostałości porządku feudalnego w układzie sił społecznych i gospodarczych; byli wśród nich: demokraci galicyjscy, pozytywiści warszawscy, organicznicy poznańscy i postępowcy z Królestwa początków XX wieku. Jedną z cech społeczeństwa obywatelskiego jest jego niezależność od państwa, czasem objawiająca się w akcie obywatelskiego nieposłuszeństwa. Polskie społeczeństwo miało częściej okazję do „ćwiczenia się" w samej kontrze wobec państwa/władzy, rzadziej jako siła niezależna od państwa; opór konstytuował siły społeczne. Może jednak była to jakaś forma przejawu ducha obywatelskiego?

Po II wojnie światowej w rzeczywistości PRL-u mieliśmy szansę dalej szlifować umiejętności budowania z jednej strony struktur przystosowawczych, z drugiej struktur oporu, odcięto natomiast Polakom możliwość budowania oddolnych struktur organizacji, dobrowolnego zrzeszania się i stowarzyszania wokół swobodnie wybieranych pól aktywności. Był to czas obywatelskiej smuty, trwający dwa razy dłużej niż czas patriotycznego zrywu po 1918 roku. Nie dziwi więc jego mocniejsze zakotwiczenie i uobecnienie w postawach i nawykach społecznych, nastapiło bowiem odtworzenie i przekazanie nowego sposobu na życie kolejnemu pokoleniu. Przedwojenne pokolenie patriotów i działaczy społecznych nie miało szansy przekazać swoich ideałów i mądrości życiowej pokoleniu powojennemu. Wielu my-

${ }^{8}$ Zob. S. Wołoszyn, Nauki o wychowaniu w Polsce w XX wieku, Kielce 1998, s. 155-162 czy szerzej A. Mencwel, Etos lewicy. Esej o narodzinach kulturalizmu polskiego, Poznań 1990.

9 Zob. szerzej M. Janowski, Polska myśl liberalna do 1918 roku, Kraków-Warszawa 1998, s. 257-281. 
ślicieli i działaczy postępowych, o ile przeżyli koszmar wojny, w nowym układzie sił było objętych represjami, szykanami ze strony aparatu władzy, wielu zmuszono do emigracji, duża część społeczeństwa nauczyła się trwać w opozycji na zasadzie emigracji wewnętrznej i przekazała tę umiejętność następnemu pokoleniu.

Ogólnie, tradycja ruchów obywatelskich miała w polskiej historii swoją mocną reprezentację głównie po stronie działaczy ugrupowań lewicowych, socjalistycznych (gł. PPS); drugie źródło wiodło do przedstawicieli bądź sympatyków myśli liberalnej. Republikańska inspiracja nakierowana była głównie na cele niepodległościowe, wszak wspólnota obywatelska nie ma szans na pełny rozwój poza wspólnota polityczna, poza państwem. Jeśli dziś możemy mówić o słabości kondycji polskiego społeczeństwa obywatelskiego, to wśród przyczyn nie można pominąć historycznego kontekstu kształtowania się polskiego społeczeństwa i narodu. To, co cywilizacyjnie sprzyja rozwojowi wspólnoty obywatelskiej, a więc swobodnie działające mechanizmy wolnego rynku, silna pozycja bogacącego się mieszczaństwa, suwerenność narodowa, rządy przedstawicielskie wszystkich szczebli, system praw gwarantowanych konstytucją, pluralizm ośrodków myśli i kształtowania opinii publicznej, tolerancja religijna, w polskiej rzeczywistości przez długi czas było dobrem deficytowym. Stąd, po pierwsze, aktywność obywatelska wcale nie była tu prowadzona głównie przez stan średni, ale przez inteligencję, działaczy katolickich a nawet postępową szlachtę, po drugie, równie mocno jak uprawnienia jednostek podkreślano więzi i zobowiązania wspólnotowe (w tym narodowe), po trzecie, liczono nie tylko na swoje zasoby społeczne ale głównie na zaangażowanie państwa i jego instrumentów (nawet zaborczych) w rozwiązywanie palących problemów zacofania, nierówności, w dziele oświecania i upowszechniania ogólnoludzkich idei i praw, i po czwarte, polskie społeczeństwo częściej organizowało się i integrowało w oporze przeciwko obcym, wrogom, zaborcom, okupantom, rzadziej łączyło się w imię jakiejś idei pozytywnej, na rzecz czegoś, stąd siła polskiego kapitału spajającego a niedobór kapitału łączącego (co widoczne jest do dziś). W takim zestroju czynników nie może też dziwić dominująca na ziemiach polskich przez cały wiek XIX tendencja uruchamiania i wzmacniania sił patriotycznych służących głównie celom narodowym (a ściśle narodowowyzwoleńczym) w mniejszym zaś stopniu obywatelskim; wszak racja moralna i pierwszeństwo należy się ruchom niepodległościowym, scalającym naród, dopiero w drugiej kolejności można decydować się na łączące inicjatywy obywatelskie. Sprzyjał temu także duch czasów, który w XIX wieku w Europie wyraźnie oscylował w kierunku szerzenia idei narodowych czy wręcz nacjonalistycznych (wrogich obywatelstwu). W stabilnej sytuacji ustrojowo-politycznej, patriotyzm i obywatelskość mogą być postawami, 
które się wzajemnie wspierają ${ }^{10}$, jednak kontekst historyczny Polski na długo przypieczętował moralną wyższość uczuć i postaw patriotycznych nad zaangażowanie obywatelskie Polaków. W XX wieku idee narodowe Europy przybrały groźniejszy kształt totalitarnych ideologii narodowosocjalistycznych i komunistycznych, które okazały się kolejnymi przeszkodami w rozwoju społeczeństw obywatelskich. Problem dotknął w większym stopniu kraje podporządkowane władzy ludowej ze względu na długi okres poddania społeczeństw demobilizującej sile totalitarnego reżimu ${ }^{11}$.

A jednak solidarnościowy zryw społeczny oraz mobilizacja sił opozycyjnych lat 80. i 90. zmieniły obraz Polski; działania obywateli okazały się skuteczne. Nasz kraj na drodze pokojowej zdołał zerwać z systemem komunistycznym i rozpoczął nowy etap budowy państwa praworządnego, demokratycznego, samorządnego, wolnorynkowego, strzegącego swobód obywatelskich. Manifest M. Ossowskiej mógł być na powrót czytany przez pokolenia rodaków. Czy ów zryw na dobre przełamał naszą tradycję jednoczenia się w walce przeciw obcej, narzuconej władzy? Czy dokonał się na bazie rodzimych inspiracji, czy w oparciu o zapożyczone wzory z Zachodu? Czy uruchomił ludzką solidarność wokół idei ładu społecznego, stabilizacji i demokracji? Od momentu zmiany ustrojowej dzieli nas już 20 lat, wyrosło więc $\mathrm{w}$ tym czasie nowe pokolenie Polaków, niepamiętające rzeczywistości PRL-u. Z jakim nastawieniem wkracza ono w dorosłość? Czy nabyło umiejętności i chęci do bycia aktywnymi obywatelami? Czy pokolenie pamiętające czasy demokracji ludowej zmieniło swoje postawy dostosowawcze? Czy jest gotowe wyjść poza postawę oporu, walki, nieufności, zwolnić pozycję emigracji wewnętrznej?

\section{Kultura rodzinna a poziom zaufania społecznego}

Powyższe pytania pozwalają nam powrócić do głównego wątku rozważań, czyli do rodzinnego środowiska życia, jako tego miejsca, w którym nabywa się podstawowe umiejętności i nastawienia do świata, innych ludzi, kultury, rynku, polityki, sacrum. Wśród przekazywanych wartości, norm i postaw rodzina tworzy też swój model odniesień wobec zaangażowania w sprawy publiczne i sfery obywatelstwa; a jako praktyka życia uczy ona

10 Zob. np. E. Shils, Co to jest społeczeństwo obywatelskie?, w: K. Michalski (oprac.), Europa i spoleczeństwo obywatelskie. Rozmowy w Castel Gandolfo, Kraków-Warszawa 1994, s. 29-31.

${ }^{11}$ Stąd trudno byłoby nie odnaleźć się choć w części w pamiętnym wizerunku homo sovieticusa, nakreślonym przez ks. J. Tischnera, zob. w: Etyka solidarności oraz Homo sovieticus, Kraków 1992. 
swych domowników wyrażania się w tych typach aktywności, które wynikają z preferowanych opcji światopoglądowych, w innych zaś objawiając bierność i obojętność. Byłoby truizmem rozszerzanie tego wywodu i przywoływanie dowodów na jego potwierdzenie; w tej kwestii, a więc w akcentowaniu dominującej roli rodziny w kształtowaniu u dzieci poglądu na świat i w budowaniu relacji z otoczeniem wśród teoretyków panuje consensus. W dziele wychowania i socjalizacji młodego pokolenia teza o niezastępowalności rodziny pozostaje w mocy. Wiedząc o tym, można natomiast próbować wglądać w ten rodzinny świat transmisji wartości i dóbr, analizować przemiany, którym podlega bądź inicjuje, badać wzajemne odniesienia łączące rodzinę z innymi elementami rzeczywistości społecznej i na koniec wspierać go. Pewne wątki z tego rodzinnego obszaru egzystencji i rozwoju człowieka, które do niedawna interesowały głównie pedagogów i socjologów rodziny, w nowej perspektywie związków i korelacji z rozwojem ekonomicznym i kondycją gospodarczą kraju zaprezentował w latach 90. F. Fukuyama w pracy pt. Zaufanie. Kapitał społeczny a droga do dobrobytu (1995, wyd. polskie 1997). Autor pokazał mianowicie, iż w całości uwarunkowań kształtowania się kapitału społecznego, a więc sieci związków międzyludzkich i podejmowanej wzajemnej współpracy, umożliwiających realizację wspólnych celów i zwiększających poziom społecznego zaufania, tak ważnych dla gospodarki i sukcesu ekonomicznego danego kraju ${ }^{12}$, ważną rolę spełniają czynniki wewnątrzrodzinne a także status rodziny w strukturze społecznej. Zainspirował więc do stawiania nowych pytań i badań w odniesieniu do rodziny.

Tam, gdzie mamy do czynienia z kultura familistyczna, tj. z typem lojalności ograniczonej głównie do kręgu spokrewnionych i z postawą nieufności wobec innych (obcych), w układzie wolnorynkowym, jak dowodzi F. Fukuyama, dominuje gospodarka o małej skali w oparciu o małe rodzinne firmy, w których brak otwarcia na menedżerską współpracę spoza kręgu rodziny. Duża skala (oparta na kooperatywie), która w dobie gospodarki globalnej stanowi drogę do dobrobytu, jest w tych krajach uzupełniana dopiero dzięki inicjatywom władz centralnych i państwa ${ }^{13}$. Skrajna postać familizmu przybiera kształt, opisany przez E. Banfielda, a później szerzej zbadany i potwierdzony przez R. Putnama, amoralnego familizmu, cechującego się typem więzi społecznych i moralnych obowiązujących jedynie w stosunku do członków rodziny, a w stosunku do innych: sąsiadów, mieszkańców okolicy, członków wspólnoty kościelnej czy społeczeństwa pozostających w relacji

12 Zob. F. Fukuyama, Zaufanie. Kapitat społeczny a droga do dobrobytu, Warszawa-Wrocław 1997, s. 13-23; por. R. Putnam, Samotna gra, s. 33-42.

${ }^{13}$ Zob. F. Fukuyama, dz. cyt., s. 36-47. 
nieufności i w poczuciu braku odpowiedzialności za losy tychże ${ }^{14}$. Społeczeństwo o takiej kulturze cechuje się niskim poziomem zaufania społecznego, brakuje w nim więzi społecznych budowanych w oparciu o spontaniczne, oddolne inicjatywy, lojalność i identyfikacja ograniczone są do rodziny i do państwa/narodu, ewent. Kościoła, w związku z tym w tak hierarchicznym społeczeństwie przeważają sieci relacji typu patron-klient. Przyglądając się takim opisom można dostrzec, że wysoka pozycja rodziny, sama w sobie stanowiąca wartość, w pewnych kontekstach (historyczno-politycznych) może zostać sprzężona z tendencjami, które nie sprzyjają rozwojowi czy wręcz go hamują. Obronno-samozachowawcze funkcje rodziny ${ }^{15}$, bądź inne, które zmuszona była na przestrzeni dziejów z różnych powodów pełnić, wpisały się w jej kulturę i kulturę społeczności, która zakonserwowana trwa, pomimo iż czynniki zewnętrzne, które wywarły na nią wpływ, dawno przeminęły. Może więc być tak, że w pewnych sytuacjach rodzina jawić się będzie jako hamulcowy przemian kraju i budowy otwartego społeczeństwa ze względu na przekazywany z pokolenia na pokolenie utrwalony typ zachowań i postaw, nacechowany nieufnością w stosunku do innych, biernością społeczną a nawet roszczeniowością w stosunku do władz.

Obserwując różne typy kultur życia codziennego Europy, Azji i Ameryki Płn., autor Zaufania doszedł do wniosku, że linia podziału między krajami o niskim kapitale społecznym z jednej i wysokim z drugiej to zarazem linia biegnąca wzdłuż lub w poprzek familizmu. Można by więc wysnuwać wniosek, że prorodzinne postawy nie idą w parze z postawami obywatelskimi; czy jest tak naprawdę? Najmocniej przeczy temu obecność społeczeństw (i to w Europie, gdzie zarówno rodzina jak i obywatelstwo posiadają w miarę utrwaloną wartość), które nie posiadają ani kapitału społecznego, ani silnej rodziny; pod ten opis podpadają kultury skrajnie indywidualistyczne, w których dodatkowo mamy do czynienia z ogólnie słabą kondycją moralnych wspólnot, a więc z deficytem samych źródeł i centrów uwierzytelniających przekaz norm, wartości i zachowań moralnych. Tak więc rodzina, która na skali wspólnot moralnych ma do spełnienia ważną (nieodstępowalną) rolę, głównie z racji budowania środowiska życia i wychowania, ale i w dziele podtrzymywania społecznej spoistości i tożsamości narodowej, jest wielkim dobrem powszechnym. Problem tkwi więc nie w ograniczaniu roli wspólnot rodzinnych opartych na więzach krwi na rzecz rozwoju sieci dobrowolnych organizacji i spontanicznych zachowań społecznych. Rodzina jako strażnik

${ }_{14}$ Zob. E. Banfield, The Moral Basis of a Backward Society, Glencoe, Ill., 1958 oraz szerzej R. Putnam, Demokracja w działaniu. Tradycje obywatelskie we wspótczesnych Włoszech, Kraków-Warszawa 1995, s. 208-225.

${ }_{15}$ Zob. A. Potocki, Wychowanie religijne w polskich przemianach, Warszawa 2007, s. $41-42$. 
cnót moralnych i społecznych to najlepszy gwarant ładu społeczno-politycznego, gospodarczego rozwoju i rozkwitu społeczeństwa obywatelskiego. Takich cnót moralnych jak uczciwość, rzetelność, lojalność, oszczędność, pracowitość, odpowiedzialność, a wśród cnót społecznych, takich jak solidarność, zaufanie, tolerancja, kooperacja nie sposób wpajać bez udziału rodziny, jako pierwszego i najważniejszego wzorca godziwego, zgodnego z zasadami życia. Problem dotyczy bardziej tego, jak sprawić, by zestaw tych cnót rodzina uczyła się stosować w szerszym kręgu społecznym a nie tylko w zawężonym do grupy „swoich”. O korzyściach, jakie współpraca, solidarność i zaufanie społeczne wnosi do życia tak jednostek, jak i wspólnot, w tym wspólnoty politycznej i gospodarczej, pisze się od dawna; klasyczna wykładnia pochodzi od A. de Tocqueville'a, który powołując się na doktrynę dobrze rozumianego interesu, wskazywał na pożytek tych naszych działań, które uwzględniają interes innych ludzi ${ }^{16}$. F. Fukuyama wyraża tę myśl słowami: ,prawo, umowa i gospodarczy racjonalizm są solidna, ale niewystarczającą podbudową stabilności i dostatku społeczeństwa postindustrialnego; należy wzmocnić je powszechną aprobatą obopólności interesów, moralnego obowiązku, służby społeczeństwu oraz zaufania - czyli wartości opartych raczej na zwyczaju niż na chłodnej kalkulacji”, które w nowoczesnym społeczeństwie są „warunkiem sine qua non jego funkcjonowania" ${ }^{17}$. W tych dwóch wykładniach daje się usłyszeć zarówno liberalny, jak i republikański sposób argumentowania za społecznym zaangażowaniem i jego ugruntowaniem w moralnej kulturze tak jednostek, jak i społeczności. Przechodząc na grunt polski, można pytać, który z nich jest bliższy naszej rodzimej myśli i praktyce, i choć trudno tu wyrokować, wydaje się, że ze względu na duży wpływ i zasięg oddziaływania nauczania Kościoła, głównie przeznaczony właśnie dla rodzin, wyraźniejszy jest republikański zestaw wartości, odwołujący się do obowiązku służby innym, dobra wspólnego, niż liberalny z kategorią interesu bądź korzyści płynącej ze współpracy z innymi. W obu podkreśla się rangę zaufania jako generalnego nastawienia $\mathrm{w}$ relacjach $\mathrm{z}$ innymi, otwierającego na dialog i współpracę, stąd pytanie o kulturę zaufania w Polsce, a także o polski familizm.

Jak pisze F. Fukuyama, zaufanie to „mechanizm oparty na założeniu, że innych członków danej społeczności cechuje uczciwe i kooperatywne zachowanie oparte na wspólnie wyznawanych normach"18. Dla A. Giddensa jest ono rodzajem zawierzenia człowiekowi bądź systemowi w konkretnej

${ }^{16}$ A nawet rozszerzając użycie tej doktryny do kwestii religijnych. Zob. A. de Tocqueville, O demokracji w Ameryce, Warszawa 2005, s. 500-504.

${ }^{17}$ F. Fukuyama, dz. cyt., s. 21.

18 Tamże, s. 38. 
sytuacji, które oparte jest na wierze w prawość tego człowieka czy miłość do niego bądź na wierze w poprawność abstrakcyjnych założeń systemu (wiedzę techniczna) ${ }^{19}$. P. Sztompka definiuje je jako „oczekiwanie godnego postępowania innych - ludzi, instytucji, organizacji - wobec nas, liczenie na ich kompetencje, uczciwość, prawdomówność" ${ }^{20}$. Zaufanie i współpraca wzajemnie się wspieraja, tak więc w społeczeństwie o wysokiej kulturze uczestnictwa zaufanie do innych jest wciąż podtrzymywane praktyką wspólnego działania. Normy wzajemności sprawdzają się i utrwalają poprzez rozszerzające się w społecznościach przyzwyczajenie do zrzeszania się, stowarzyszania, spotykania się w klubach, grupach wsparcia, kościołach i innych miejscach swoistych dla danej wspólnoty lokalnej. Zaufanie jest nieodłączne od tego typu miejsc, tak że trudno jest nawet orzec, czy jest ono skutkiem czy przyczyną podejmowania wspólnych inicjatyw. Takie ujęcie sprawy wydaje się prezentować R. Putnam, śledząc losy bardzo kiedyś obywatelskiego społeczeństwa amerykańskiego, a dziś doświadczającego kryzysu zaangażowania symbolizowanego postacią samotnego kręglarza.

Polska rzeczywistość nie przypomina społeczeństwa amerykańskiego, na pewno brakuje nam podobnej tradycji zrzeszania się, tworzenia oddolnych inicjatyw i działania wzajem bez oglądania się na zwierzchność i autorytety. Znamy kontekst historyczny, który w dużej mierze tłumaczy to zjawisko, wyjaśnia też źródło wielkich pokładów nieufności, przenoszonych z pokolenia na pokolenie i dziś jeszcze pielęgnowanych w wielu środowiskach i kulturach rodzinnych. Stąd nasze dzieci z reguły nie mają możliwości oglądania swoich rodziców jako aktywnych członków lokalnej społeczności (co potwierdzają wszelkie badania empiryczne). Jeśli uczą się zaangażowania społecznego, impuls nie pochodzi od rodzin, jest generowany działaniami głównie instytucji edukacyjnych. Czy to ów brak kultury uczestnictwa jest przyczyną niskiego poziomu zaufania społecznego, czy raczej brak zaufania wywołuje swój skutek w postaci bierności społecznej? To pytanie nie ma łatwej odpowiedzi; w naszej kulturze oba deficyty po prostu wzajemnie się napędzają i wzmacniają. Nawet czas mijającego 20-lecia nie jest wolny od nowych zagrożeń pod budowę obywatelskiej wspólnoty ${ }^{21}$. Osobiście przychylam się do stanowiska, by stawiać na poprawę kultury uczestnictwa

19 Zob. A. Giddens, Konsekwencje nowoczesności, Kraków 2008, s. 24-25.

20 P. Sztompka, O potrzebie wspólnoty obywatelskiej, ,Europa. Tygodnik idei” 21 (2006), s. 12.

${ }^{21}$ P. Sztompka nazywa je czasem doświadczania czterech traum społeczno-kulturowych: dziedzictwa homo sovieticus, transformacji i reform systemowych, słabości elit politycznych oraz IV Rzeczypospolitej. Zob. tenże, Zaufanie i wspótpraca: fundament rozwoju Polski, wystąpienie na II Ogólnopolskim Kongresie Obywatelskim w Warszawie 10.03.2007, opublikowane pod tytułem Trauma IV RP, „Europa. Tygodnik idei” 12 (2007), s. 12-13. 
różnorakimi środkami, o czym będzie jeszcze mowa, głównie w stosunku do młodego pokolenia, co powinno przełożyć się również na wzrost poziomu społecznego zaufania.

Rodziny polskie, w moim przekonaniu, stanowią bogaty rezerwuar cnót, postaw, nawyków i zachowań, które przez wieki sprawdziły się w obronie siły polskiego narodu; dziś ten rezerwuar, mocny patriotyzmem i katolicyzmem $^{22}$, ale także wspierany innymi tradycjami ideowymi, powinien móc w równym stopniu pobudzić podmiotowość społeczną w polskim społeczeństwie i ożywić je jako obywatelską wspólnotę, solidarne społeczeństwo. Kluczem do tego jest, posługując się znów terminologią R. Putnama, umożliwienie, różnymi środkami, przekroczenia przez naszą wrażliwość społeczną progu kapitału spajającego (bonding) i większe otwarcie się na walory kapitału łączącego (bridging) ${ }^{23}$. Potrzebujemy impulsów, które równolegle z pielęgnowaniem naszych sprawdzonych więzi wspólnotowych, integrujących od środka, zapewniających poczucie bezpieczeństwa i wspierających poczucie tożsamości, rozszerzą nasz horyzont bycia o nowe rozleglejsze tożsamości dzięki perspektywie współpracy i otwarcia na innych, wchodzenia w relacje o słabszej sile lojalności ale równie satysfakcjonujących i umożliwiających realizację różnorakich celów, w tym rozwiązywanie problemów. Poza wymiarem indywidualnych korzyści z kapitału łączącego $\mathrm{w}$ grę wchodzą także korzyści dla całości społeczeństwa, które silniejsze siecią wzajemnych związków nabywa skuteczną ochronę przed rosnącymi zakusami władzy, by w obliczu słabej kondycji obywatelskiej swojego ludu poszerzać obszary swej plenipotencji.

Oba wymiary kapitału społecznego: spajający i łączący nie mają charakteru rozłącznego czy wymiennego. Dobrze to widać na przykładzie rodziny. Trudno byłoby sobie nawet wyobrazić dobrze funkcjonującą rodzinę bez jej kapitału spajającego. Symboliczna jest w niej rola opisanej przez E. Eriksona $^{24}$ podstawowej ufności, która rodzi się w dziecku w odpowiedzi na miłość, akceptację, troskę, wiarygodność i odpowiedzialność jego rodziców, stanowiąc swoisty budulec pod budowę przyszłej prawidłowej osobowości rozwijającego się dziecka. Najbliżsi, dając siebie dziecku, uczą, że możliwe jest zaufanie i wyjście z nim ku innym, zapewniając zgodność, konsekwencję, ciaggłość i identyczność doświadczeń, oraz nakreślając sferę zakazów i przyzwoleń umożliwiają nabywanie orientacji w świecie i poczucia jego

22 Jako polskim dziedzictwem, które wg P. Sztompki stanowi ważne źródło naszego poczucia wspólnoty i zaufania. Zob. wywiad z P. Sztompką, pt. Nie ufaj nikomu, „Gazeta Wyborcza”, 1-2.12.2007, s. 20.

${ }_{23}$ Zob. R. Putnam, Samotna gra, s. 40-42.

${ }^{24}$ Zob. E. Erikson, Dzieciństwo i spoleczeństwo, Poznań 2000, s. 257-261. 
realności. Stan ufności to gwarant przyszłej stabilnej tożsamości, poczucia bycia sobą, nabywania wiary w siebie, podstawa bezpieczeństwa ontologicznego a zarazem łącznik ze światem. Jeśli mocne spajające więzi wewnątrz rodziny są tak optymalne dla rozwoju dzieci ${ }^{25}$, powstaje pytanie o szanse godzenia go z kapitałem łączącym, i czy w ogóle leży on w interesie rodziny. Okazuje się, że tak. Dobrze to dokumentuje R. Putnam, wskazując na duże obszary zaangażowania społecznego otwierające się właśnie przed rodzicami. Mieszczą się tu działania wokół wspierania czy kontroli instytucji edukacyjnych, w których przebywają ich dzieci, zwiększone zainteresowanie udziałem w praktykach religijnych, znów często motywowane dobrem dzieci i wyobrażeniami o dobrze funkcjonującej rodzinie, a także nowe zadzierzgnięte relacje towarzyskie pomiędzy rodzicami wspólnie bawiących się czy uczących dzieci. Kapitał społeczny przejawiany w postawach i zachowaniach rodziców (zaufanie do innych, udział w organizacjach, w życiu parafii, wolontariat, udział $\mathrm{w}$ wyborach, nieformalne relacje towarzyskie z przyjaciółmi) okazuje się być wyraźnie pozytywnie skorelowany z sukcesami szkolnymi ich dzieci a także z ogólnie dobrym ich rozwojem ${ }^{26}$. Wymaga to jednak klimatu społecznego wyraźnie wspierającego takie postawy i zachowania. Sprzyja temu jednoznacznie stabilizacja polityczna i gospodarcza kraju, sprawne funkcjonowanie instytucji użyteczności publicznej (zaufania publicznego), szacunek władz wszelkiego szczebla w stosunku do obywatela i przestrzeganie prawa przez instytucje, pierwszeństwo racji publicznej (dobra wspólnego) w działaniach rządzącej partii i opozycji oraz czynniki pokrewne składające się na całość, jaką jest stabilna i sprawiedliwa demokracja. W przeciwnym razie familizm, czyli owo zamknięcie się w kręgu rodziny (powrót do kapitału spajającego), o ile staje się kulturowo ugruntowaną tendencją społeczną w odpowiedzi na ogólną niestabilność i zmienność bądź niepewność reguł obowiązujących w społeczeństwie, może się okazać nawet najlepszym z możliwych, z punktu widzenia dobra jej domowników, rozwiązań.

O zmianie mentalnej, która ewentualnie wytworzy bądź przywróci sieć społeczną, zaufanie i normy wzajemności, będzie więc można mówić dopiero wtedy, gdy oprócz przemian w indywidualnym podejściu do obywatelstwa i społecznego zaangażowania pojawią się działania naprawcze o zasięgu publicznym, instytucjonalnym. Na gruncie polskim ten wymiar, a więc doskonalenie samych struktur państwa prawa oraz funkcji rządzenia od szczebla lokalnej władzy samorządowej po instytucje władzy centralnej, wydaje się być kluczowym. Wyniki badań opinii publicznej były przez lata w tej materii

${ }^{25}$ Zob. R. Putnam, Samotna gra, s. 592.

${ }^{26}$ Zob. tamże, s. 485-501. 
nieubłagane; jeszcze w 2007 roku (gdy temperatura sporów między ugrupowaniami politycznymi w walce o IV RP była nad wyraz wysoka) poziom zaufania społecznego mierzony stosunkiem obywateli do elit politycznych i instytucji publicznych nie przekraczał $10 \%$, by nie wspomnieć o znikomym w tamtym czasie zaufaniu przedstawicieli poszczególnych ugrupowań pomiędzy sobą (Eurobarometr z III 2007). Nie był to klimat sprzyjający podejmowaniu współpracy dla wspólnej sprawy ${ }^{27}$; był to kolejny raz klimat walki z przeciwnikiem ${ }^{28}$. Na szczęście kolejne badania poczynając od 2008 roku pokazują już tendencję wzrostową w poziomie uogólnionego zaufania (z 17\% w 2007 do 26\% w 2008 wg CBOS), a także w stosunku do wybranych instytucji publicznych.

Nakreślony do tej pory obraz byłby jednak niepełny, gdybyśmy na tym poziomie analizy nie odnieśli się do roli, jaką na mapie instytucji o zasięgu ogólnopolskim spełnia, w dziele budzenia świadomości społecznej, Kościół katolicki. Jest to w opinii rodaków jedna z najbardziej cenionych instytucji, ciesząca się wysokim poziomem zaufania społecznego. Do tej pory mało przeze mnie eksponowana rola Kościoła wymaga poświęcenia mu odrębnej uwagi ze względu na wyraźnie dominującą pozycję religii katolickiej w procesie kształtowania światopoglądu i postaw Polaków. Zaświadcza o tym coniedzielne nauczanie duszpasterskie w kościołach, z którego systematycznie korzysta połowa wierzących, następnie powszechna katecheza szkolna, a także obecność głosu Kościoła w mediach i w debacie publicznej, podczas wymiany argumentów za i przeciw (głównie natury moralnej) w różnych spornych kwestiach społeczno-kulturowych czy nawet ekonomicznych wiążących politycznie.

\section{Rodzina polska a Kościół}

Można się tylko cieszyć z faktu powszechnego uznania dla wysokiej rangi Kościoła w Polsce. Składa się na to wiele prób, przez które przechodził on w dziejach narodu i za które wystawiano mu, gdy reprezentował głos ludu, wysoką notę. Taki wizerunek utrwalił się w ocenie wkładu Kościoła w trwanie narodu podczas zaborów, później potwierdzony dodatkowo ofiarą złożoną podczas wojen światowych. Bliższy nam czas ludowej demokracji

27 Zob. P. Sztompka, Trauma IV RP, s. 12.

28 Jego ślad wybrzmiał mocno jeszcze podczas tegorocznych obchodów 20. rocznicy powołania pierwszego demokratycznego rządu w wolnej od komunizmu Polsce, podczas których klasy politycznej nie było stać na zgodne upamiętnienie tego wydarzenia w wymiarze jednoczącym, ponad podziałami, w kategoriach dobra wspólnego, tym samym brakiem naznaczone są coroczne uroczystości upamiętniające podpisanie porozumień sierpniowych z 1980 roku. 
to okres, który zapisał się w świadomości Polaków szczególnie, poczynając od awangardowego listu biskupów polskich do niemieckich w 1965 roku ze słowami „przepraszamy i prosimy o przebaczenie”, przez dzieło przekazu duchowych treści w homiliach, które odbarczały i pozwalały niejako lżej doświadczać bolączek codzienności naznaczonej brakiem, zależnością od władz i wszechobecnością ideologii marksistowskiej, podtrzymując ducha wspólnoty na przekór szarej rzeczywistości, kończąc na wkładzie duchowieństwa w podtrzymywanie rodzących się opozycyjnych ruchów, co znalazło swój wyraz w dawaniu schronienia działaczom opozycyjnym czy organizowaniu akcji pomocowych dla represjonowanych i ich rodzin. Walka z Kościołem, prowadzona przez system, niemający legitymizacji społecznej, tylko tę instytucję wzmacniała. Dzięki współpracy z duchowieństwem możliwe stawało się dotarcie do wiernych z apelami i przesłaniem ideowym świeckiej opozycji, z twórczością ludzi kultury, z myślą ze świata nauki, wygłaszanymi i prezentowanymi w murach kościelnych, choć często reprezentujących zgoła nie religijny punkt widzenia. Kulminacją pozytywnego wpływu Kościoła na polską powojenną rzeczywistość stał się wybór na Papieża Kardynała Karola Wojtyły. Ruch Solidarności, ten masowy obywatelski zryw, ma bez wątpienia w Papieżu Janie Pawle II swojego patrona. Wielu uznaje w Nim także ważnego aktora na scenie demontażu całego systemu władzy komunistycznej w krajach Europy środkowo-wschodniej. Papież wzmacniał nasze morale podczas swych pielgrzymek do Polski, postulował nowy styl bycia katolikiem, wspierał starania rodaków na drodze pokojowego przejęcia władzy i tworzenia demokratycznego rządu, popierał nasz akces do Unii Europejskiej. Te i wiele innych dokonań Kościoła leży u podstaw utrwalonego społecznie pozytywnego obrazu jego zasług.

W dzisiejszym świecie późnej nowoczesności, z otwartymi granicami, swobodnym przepływem kapitału, idei, z pluralizacją poglądów i sekularyzacją wielu dziedzin życia, większość Polaków podtrzymuje swój kontakt z Kościołem i jego przekazem treści wiary. Myśl chrześcijańska stanowi wciąż ważne źródło, z którego kolejne pokolenia czerpią poczucie sensu, znajdują odpowiedź na pytania egzystencjalne dotyczące dobrego spełnionego życia i budowania wspólnot z innymi, w tym wspólnoty małżeńskiej i rodzinnej ${ }^{29}$. Kościół katolicki dociera z posługą do każdej zbiorowości zamieszkanej przez chrześcijan. Wspólnoty parafialne to dla obserwatora zwarte masowe grupy uczestników nabożeństw, których łączy wiara w jednego Boga. Jednak czy ta wspólna wiara łączy ich między sobą i orientuje na świadome uczestnictwo? Czy staje się źródłem zagospodarowanej wspól-

29 Zob. J. Mariański, Kościót katolicki w Polsce a życie społeczne. Studium socjologiczno-pastoralne, Lublin 2005, s. 252-263. 
nym działaniem przestrzeni parafii? Baczny obserwator tu dopiero dostrzeże pierwsze braki, bowiem o ile statystyka deklaracji wiary i uczestnictwa w nabożeństwach jest wysoka (nawet wśród młodzieży), to jednocześnie zatrważająco niski jest procentowy udział wiernych w życiu swojej parafii. Socjologowie religii przyznają, że polską religijność cechuje głównie obrzędowość, wyrażająca się w praktykach kultowych i zaspokajających indywidualne (nie zaś wspólnotowe) potrzeby religijne ludzi ${ }^{30}$. Dlaczego wspólna wiara nie wyzwala pozytywnej energii do budowania więzi wokół innych wspólnych celów? Jakie są tego przyczyny?

Znów na początek trzeba sięgnąc do naszych trudnych naznaczonych cierpieniem dziejów. Kościół spełniał częstokroć zastępczo role przynależne państwu i instytucjom świeckim, chroniąc przed zaborcą, okupantem, reżimem, budząc ducha oporu w imię wielkich idei. Dziś dalej zdarza mu się pozostawać przy tej wykładni walki, tym razem z wrogiem czającym się u wrót nowoczesnego świata pod postacią: rynku i wielkiego kapitału, ślepego na potrzeby biednych a człowieka sprowadzającego do poziomu konsumenta, państwa jako bezdusznego aparatu biurokracji czy mediów, cynicznych i żerujących na taniej sensacji, itp. Krytyka dzisiejszej pozbawionej odniesienia do Boga rzeczywistości, głoszona z ambon, wielu wierzących ustawia w pozycji nieufności i wycofania w bezpieczną sferę prywatności domu, rodziny, z dala od niepewnego zaborczego bezbożnego świata, ewentualnie zamyka w kręgu przeciwnych różnym zjawiskom nowoczesności ekskluzywnych wspólnot religijnych przypominających „kulturowe getta”

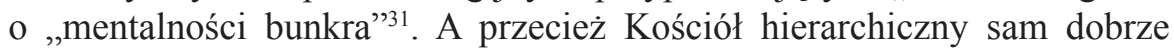
odnajduje się w świecie globalnego kapitału, zgłębia jego mechanizmy dla dobra swej instytucji, służącej trwaniu na ziemi wiecznych prawd bożych. Taką strategię, uczenia aktywności i przedsiębiorczości a nie podtrzymywania lęku, nieufności czy nawet resentymentu, można by stosować z równie dobrym skutkiem w naszych parafiach. Tymczasem opozycja między bogatymi i biednymi (podobnie jak szersze kategorie: „my” i „oni”) to wciąż żywe źródło antagonizmów niewygasłe w samym Kościele, natomiast cnota zaradności należy do tych z rzędu pozornych czy podejrzanych cnót. Chrześcijanin w Polsce nie wszystkim też kojarzy się z życzliwą, otwartą osoba, nierzadko prezentuje on uczucia nieufności i niechęci, o różnej skali natężenia, niekoniecznie przez duszpasterzy wygaszane, czasem nawet podtrzymywane, a przeznaczone dla niemałej grupy „wrogów Kościoła”.

${ }^{30}$ Zob. tenże, Kościót katolicki w społeczeństwie obywatelskim. Refleksje socjologiczne, Lublin 1998, s. 118, 138.

${ }^{31}$ Zob. tamże, s. 142. 
Poza historycznym bagażem ciążącym na dzisiejszym stanie bierności i wycofania z życia wspólnotowego parafii wskazałabym jeszcze na trzy inne przyczyny niedorozwoju naszego chrześcijańskiego społeczeństwa obywatelskiego ${ }^{32}$. Po pierwsze, sztywne struktury organizacji i władzy w całym Kościele jako instytucji ściśle hierarchicznej, często opornie nastawionej na jakiekolwiek elementy demokratyzacji. Przewaga stylu autorytarno-nakazowego w kierowaniu parafią, brak bądź słabość (fasadowość) Duszpasterskich Rad Parafialnych, rozpisane odgórnie role dla poszczególnych „stanów” w życiu parafii, w tym dla młodzieży, to przykłady instytucjonalnych barier po stronie Kościoła niesprzyjających budowaniu oddolnych inicjatyw, spotykania się z inspiracji religijnych czy choćby z samej chęci robienia czegoś razem z innymi w Kościele lokalnym. Młodzi grupują się więc poza Kościołem, bo instytucja, posiadająca rozbudowaną infrastrukturę (salki katechetyczne, zaplecza kościołów), lęka się spontanicznej aktywności młodzieży i nie wychodzi z inicjatywą przyciagnięcia nowymi formami organizacji czasu wolnego, pozostając na bezpiecznej i sprawdzonej pozycji patronackiej, jako agencja służąca spełnianiu indywidualnych i rodzinnych usług religijnych. Idea „nowej epoki zrzeszeń” w Kościele, głoszona przez Jana Pawła II, wciąż czeka na podatny grunt; podobnie jak aktualny pozostaje papieski apel do biskupów z 1993 roku, by niwelować pionowy wymiar $w$ relacjach między proboszczami a parafianami na rzecz wzajemnej współpracy, dialogu, służby i obustronnego zaufania ${ }^{33}$. Po drugie, przeniesienie katechezy do szkół i uczynienie z niej jednego z przedmiotów szkolnych, i do tego ocenianych. Obok wymiernych korzyści decyzja ta przyniosła jednak także straty ${ }^{34}$, choćby w postaci oddalenia się dzieci i młodzieży, stanowiących grupy najbardziej chętne i podatne na bodźce zachęcające do działania na rzecz innych i z innymi, od parafii, w której te działania mogłyby zaistnieć. Wynik tego oddalenia to utrata mentalnego, emocjonalnego i moralnego poczucia więzi z parafią, za która, co wykazują badania, młodzi nie czują się odpowiedzialni (bo nie czują się rzeczywistymi podmiotami w życiu Kościoła). I po trzecie, brak wystarczającej wiedzy społecznej i filozoficznej ${ }^{35} \mathrm{w}$ kształceniu przyszłych kapłanów, oswajającej

${ }^{32}$ Pojęcie to, celne i wartościowe, wciąż czeka na głębsze zrozumienie i recepcję w polskiej myśli społecznej i katolickiej. Zob. J. Gowin, Sześć tez na temat wolności i religii. Chrześcijanin i obywatel, „Europa. Tygodnik idei” 22 (2008), s. 12-13.

33 Zob. J. Mariański, Kościół katolicki w społeczeństwie obywatelskim, s. 136 i 144.

${ }^{34}$ Bilans korzyści i strat. Zob. szerzej A. Potocki, Wychowanie religijne, s. 255-258.

${ }^{35}$ O dobry poziom nauczania filozofii w seminariach dopominał się Jan Paweł II w swej encyklice Fides et ratio, a teologów w tym miejscu zachęcał, „by na nowo odkryli i jak najpełniej ukazali metafizyczny wymiar prawdy, a w ten sposób nawiązali krytyczny i rzetelny dialog ze wszystkimi nurtami współczesnej myśli filozoficznej i całej filozoficznej tradycji, zarówno 
i uczącej rozumieć coraz szybciej zachodzące zmiany dokonujące się w życiu nowoczesnych społeczeństw, jak i z ideami, głoszonymi przez świeckie elity, docierającymi medialnymi kanałami do mas społecznych. Ten stan nieufności, nierozumienia i niezgody na dzisiejszy zsekularyzowany świat daje efekt w postaci ześrodkowywania całej energii duszpasterskiej na krytyce ubranej w moralizatorski ton i nauczaniu prawd wiary w oderwaniu od kontestowanej rzeczywistości, w ciągłym stanie zawieszenia „między niebem a ziemią" ${ }^{36}$. Zaproszenie do współpracy i konkretnych propozycji działania na terenie parafii ze strony jej włodarzy wymaga wiedzy (choćby podstaw zarządzania, komunikacji społecznej czy animacji społecznej) i dialogu ze współczesnością, a więc zmiany nastawienia i większej otwartości.

Tych kilka opisanych przyczyn oddziałujących razem zwielokrotnia efekt bierności, tak więc „rewolucja uczestnictwa” wiernych pozostaje wciąż niezrealizowanym projektem Kościoła, a może nawet wciąż nieprzyjętym powszechnie przez duchowieństwo. Jest to tym bardziej zastanawiające, że jednocześnie podstawową zasadą moralną z którą utożsamia się większość Polaków, jest przykazanie miłości bliźniego. Nie zmienia nakreślonej wyżej diagnozy obecność „oaz uczestnictwa”, chlubnych przykładów tak z życia parafialnego, jak i może częściej z działalności duszpasterskiej niektórych zgromadzeń zakonnych (np. ojców dominikanów, franciszkanów) ożywiania społeczności wokół różnych inicjatyw (prócz ściśle religijnych także charytatywnych, sportowych, edukacyjnych, artystycznych, rekreacyjnych, obywatelskich), wartościowych i czekających na upowszechnienie. Takie inicjatywy, choć nie adresowane wprost do całych rodzin, i tak je wzmacniaja, bo aktywizują poszczególnych jej członków (w grupach dzieci, młodzieży, rodziców czy dziadków).

\section{„Nowoczesne” bariery rozwoju wspólnot lokalnych}

Wszystkie do tej pory omówione bariery rozwoju społeczeństwa obywatelskiego w Polsce, specyficzne dla naszego kontekstu kulturowego, trzeba jeszcze uzupełnić czynnikami ryzyka, które biegną niezależnie, a związane są z przemianami nowoczesnych społeczeństw i mogą nakładać się na te wcześniejsze. Za R. Putnamem, który badał przyczyny upadku wspólnot lokalnych w Stanach Zjednoczonych w ostatnich dziesięcioleciach, można tu wymienić takie zjawiska, jak: intensywność wysiłków związanych z pracą

z tymi, które pozostają w zgodzie ze słowem Bożym, jak i z tymi, które są z nim sprzeczne" (nr 105).

${ }^{36}$ Zob. A. Potocki, Wychowanie religijne, s. 258-272. 
zawodową i jej utrzymaniem, czyli „pogoń za pieniędzmi”, niepokój o sytuację materialną, kariera zawodowa obojga rodziców, presja czasu, niekontrolowany rozrost miast (suburbanizacja, w tym zamknięte strzeżone osiedla), dojazdy do pracy, umasowienie elektronicznej komunikacji i rozrywki, głównie telewizji (choć dziś chyba przewagę przejmuje internet), słabnące $\mathrm{z}$ pokolenia na pokolenie więzi rezydentalne, religijne i organizacyjne, związane z poczuciem przynależności do swojej okolicy, kościoła czy grup i organizacji, w wyniku większej mobilności społecznej ${ }^{37}$. Z naszego punktu widzenia szczególnie ważna okazuje się konstatacja autora o niewystarczalności obecności nawet „długiego pokolenia obywatelskiego” (w przypadku USA chodzi o roczniki z lat 20. i następne, pamiętające czas II wojny światowej, mobilizującej do wspólnego działania), by zapobiec rozpraszaniu się społecznych sił w narodzie, bowiem gwałtownie zachodzące zmiany cywilizacyjne powodowały, iż z pokolenia na pokolenie stopniowo wytracało ono swą zdolność przekazu postaw uspołecznienia swoim dzieciom i wnukom. Trudno nie porównywać tej sytuacji z Polską powojenną, która gwałtownie, środkami represji, wyciszyła ducha obywatelskiego przedwojennego pokolenia Polaków, rodząc próżnię społeczną między rodziną a narodem. Dziś to pole zaczyna być zagospodarowywane ale widać wyraźnie, choćby dzięki porównaniu z USA, że nie może to być zadanie tylko dla rodzin, a może nawet w małym stopniu dla nich. Te, w roli gniazda cnót, stanowią najlepszy fundament pod budowę społeczeństwa obywatelskiego. Pobudzanie do społecznego zaangażowania jest zadaniem rozpisanym na wiele podmiotów, w tym państwo, samorządy lokalne ${ }^{38}$, szkoły i inne instytucje edukacyjne ${ }^{39}$, organizacje pozarządowe, zakłady pracy, ośrodki naukowe, media oraz Kościól. Idąc za R. Putnamem, można tylko powtórzyć jego słuszny apel, by budować program „kapitalistów społecznych” wielotorowo z odwołaniem się do wszystkich podmiotów życia społecznego ${ }^{40}$. Warto skorzystać z tego amerykańskiego wzoru propozycji na naszym rodzimym gruncie. Ze swojej strony chciałabym jednak na koniec skupić uwagę i zaakcentować rolę jednego $\mathrm{z}$ tych podmiotów, którego wpływ na polskie rodziny jest największy, a mianowicie Kościoła katolickiego. Sądzę, że z uwagi na katolickość większości polskich rodzin, bez wkładu duchowieństwa w to dzieło, a więc

37 Zob. R. Putnam, Samotna gra, s. 307-469.

${ }^{38} \mathrm{~Np}$. w środowisku krakowskim rozwijane są od kilku dobrych lat inicjatywy samorządowe aktywizujące społecznie młodzież gimnazjalną, warte upowszechniania w skali kraju. Zob. na ten temat np. T. Talaczyński, Samorzqd Uczniowski: raczej szansa niż kłopot, „Wychowawca” 11 (2007) oraz strona www.mpppm.pl.

39 Zob. np. K. Wrońska, Wartości obywatelskie w życiu szkoły, „Hejnał Oświatowy”, nr 3/77 (2008), s. 13-17.

${ }^{40}$ Zob. R. Putnam, Samotna gra, s. 653-674. 
bez zaangażowania poszczególnych księży w sieci parafii ${ }^{41}$ i zgromadzeń zakonnych, kształtowanie cnót społecznych i budzenie obywatelskiego ducha naszego społeczeństwa długo jeszcze będzie tylko projektem, idea, względnie niszową formą spontanicznej samorealizacji nielicznych. Wszystkie inne próby i wysiłki na tym polu, poczynając od państwa, kończąc na mediach, cenne i potrzebne, mogą okazać się mało efektywne (tak jak jest do tej pory), jeśli do gry nie wejdzie Kościół. Na szczęście projekt chrześcijańskiego społeczeństwa obywatelskiego i postulowanie solidarności obywatelskiej ma swoich promotorów również w łonie Kościoła, a także wśród przedstawicieli klasy politycznej.

\section{Parafia jako wspólnota wspólnot}

Ożywiona aktywnością wiernych parafia to jak na razie głównie idea, ale interesująco określona w piśmiennictwie katolickim mianem „wspólnoty wspólnot"42. Według mnie, jest to klucz do budowy w Polsce społeczeństwa obywatelskiego w rękach duchowieństwa i aktywnych działaczy katolickich, bez których polski familizm z jego pielęgnowaną nieufnością stanie się hamulcowym pozytywnej zmiany społecznej. Potrzebna jest jednak zmiana przekonania, a mianowicie, że aktywni parafianie to nie kłopot ale korzyść dla Kościoła, a zaangażowanie to wzbogacenie treści życia chrześcijańskiego, do tego postulowane w 5. przykazaniu kościelnym (,troszczyć się o potrzeby wspólnoty Kościoła"). Apel R. Putnama do amerykańskiego kleru, przywódców świeckich, teologów i zwykłych wyznawców brzmiał: „wywołajmy nowe, pluralistyczne, społecznie odpowiedzialne «wielkie przebudzenie», tak żeby w 2010 roku Amerykanie byli bardziej zaangażowani, niż są dziś, w tę lub inną duchową wspólnotę znaczeń, jednocześnie stając się bardziej tolerancyjni wobec wiary i praktyk innych Amerykanów"43. W Polsce mógłby mieć on formę wezwania do szerszego otwarcia kościołów dla swych parafian, tak by poczuli się jako laikat podmiotem a nie, jak dziś, przedmiotem duszpasterstwa. W tym celu potrzeba zachęty do tworzenia na terenie parafii małych grup, które łączyłyby różne formy wspólnych zainteresowań, tworzących nowe poziome więzi między ludźmi, niekoniecznie mocno związanych z Kościołem ale przyciaganych doń dzięki otwarciu i życzliwości reprezentantów tego środowiska. Jak pisze dominikanin ks. A. Potocki, którego refleksją chciałabym się tu wesprzeć, jako w pełni od-

${ }^{41}$ Zob. J. Mariański, Udziat katolików świeckich w życiu parafii, Płock 2008, s. 97-112.

${ }^{42}$ Zob. np. A. Potocki, Jakiej potrzebujemy parafii?, „Teofil” nr 1/27 (2008), s. 125-141.

${ }^{43}$ R. Putnam, Samotna gra, s. 665. 
dającą również mój punkt widzenia na sprawę, przeciwwagą dla skostnienia życia parafialnego „,chciałoby się widzieć styl demokratyczny - styl na nasze czasy i na polskie warunki, bo dobrze korespondujący z postulatami społeczeństwa obywatelskiego. Jest on koniecznością jeśli chcemy przechodzić od Kościoła klerykalnego do Kościoła ludu Bożego"44. W nowej strukturze, wypełnionej małymi grupami, byłoby miejsce dla każdego parafianina, o ile by tego chciał. Dawałyby one szansę na realizację siebie na różnych polach działania z innymi zgodnie z własnymi preferencjami i budowania przestrzeni wzajemnego zaufania, życzliwości, współpracy, fundamentu wspólnoty obywatelskiej. „Dzięki takim umiejętnościom - pisze ks. A. Potocki - parafia, nie czekając na «klientów», którzy przyjdą lub nie, zaistnieje poza przestrzenią świątyni”"45. To tu mogą kształtować się elity ,zdolne do przekraczania granic parafii i umiejące być obecnymi w sprawach publicznych. Oto nowe zadanie parafii: być oparciem dla laikatu działającego w świecie. Działającego na własną odpowiedzialność. Działającego nie pod ochronnym parasolem Kościoła, ale przecież mocno w nim - poprzez parafię właśnie - zakorzenionego" ${ }^{46}$. Właśnie taką drogę, przez budowanie nowej formuły parafii jako wspólnoty wspólnot i otwieranie się na oddolne uczestnictwo i aktywność laikatu (dzieci, młodzieży, rodziców, dziadków), oceniam jako najefektywniejszą w dziele upodmiotowienia społecznego naszych rodaków. Ten nurt odnowy odblokowałby zarazem inne drogi budowania otwartego społeczeństwa, ale to już temat na odrębną pracę.

\section{Christian family as basis for civil society (Summary)}

This text is an attempt to describe mutual relations between family and civil society in Polish reality. It does research work on historical and cultural conditions for faint rootedness of civic attitudes and commitment in our society. It poses a question on causes of low level of social trust and describes Polish familism in their mutual relation. It takes into consideration the role of Catholic Church as the institution which is constantly and deeply present in the life of most polish families and has much influence. This context indicates that there are both a possibility and need to build a Christian civil society in Poland. A new formula of parish as a community of communities is its exemplification. Activity of Church and other agents of public

\footnotetext{
${ }^{44}$ A. Potocki OP, Jakiej potrzebujemy parafii?, s. 136.

45 Tamże, s. 140.

46 Tamże, s. 141.
} 
life (mainly: local authorities, media, educational institutions, NGO's, government, works and employers) in support of civil society in our country is an attempt to strengthen, beside the bonding capital necessary in the family and national life, the bridging capital which enables to build the new social ties and commitments basing on mutual trust, benevolence and cooperation with others. 
